\title{
Ethanol Dehydrogenation to Acetaldehyde over Activated Carbons-Derived from Coffee Residue
}

\author{
Jeerati Ob-eye, Piyasan Praserthdam, Bunjerd Jongsomjit* \\ Center of Excellence on Catalysis and Catalytic Reaction Engineering, Department of Chemical \\ Engineering, Faculty of Engineering, Chulalongkorn University, Bangkok 10330, Thailand
}

Received: $2^{\text {nd }}$ October 2018; Revised: $9^{\text {th }}$ November 2018; Accepted: $25^{\text {th }}$ November 2018; Available online: 30th April 2019; Published regularly: 1't August 2019

\begin{abstract}
This study focuses on the production of acetaldehyde from ethanol by catalytic dehydrogenation using activated carbon catalysts derived from coffee ground residues and commercial activated carbon catalyst. For the synthesis of activated carbon catalysts, coffee ground residues were chemical activated with $\mathrm{ZnCl}_{2}$ (ratio 1:3) followed by different physical activation. All prepared catalysts were characterized with various techniques such as nitrogen physisorption (BET and BJH methods), scanning electron microscopy (SEM), energy dispersive X-ray spectroscopy (EDX), temperature programmed desorption ( $\mathrm{CO}_{2}$-TPD and $\mathrm{NH}_{3}$-TPD), X-ray Diffraction (XRD), Fourier transform infrared spectrometer (FT-IR), and thermogravimetric analysis (TGA). The dehydrogenation of vaporized ethanol was performed to test the catalytic activity and product distribution. Testing catalytic activity by operated in a fixed-bed continuous flow micro-reactor at temperatures ranged from 250 to $400{ }^{\circ} \mathrm{C}$. It was found that the AC-D catalyst (using calcination under carbon dioxide flow at $600{ }^{\circ} \mathrm{C}, 4$ hours for physical activation) exhibited the highest catalytic activity, while all catalysts show high selectivity to acetaldehyde (more than 90\%). Ethanol conversion apparently increased with increased reaction temperature. At $400{ }^{\circ} \mathrm{C}$, the AC-D catalyst gave the highest ethanol conversion of $47.9 \%$ and yielded $46.8 \%$ of acetaldehyde. The highest activity obtained from AC-D catalyst can be related to both Lewis acidity and Lewis basicity because the dehydrogenation of ethanol uses both Lewis acid and Lewis basic sites for this reaction. To investigate the stability of catalyst, the AC-D catalyst showed quite constant ethanol conversion for $10 \mathrm{~h}$. Therefore, the synthesized activated carbon from coffee ground residues is promising to be used in dehydrogenation of ethanol. Copyright (C) 2019 BCREC Group. All rights reserved
\end{abstract}

Keywords: Ethanol Dehydrogenation; Acetaldehyde; Activated carbon; Coffee ground residues; Lewis acidity and Lewis basicity

How to Cite: Ob-eye, J., Praserthdam, P., Jongsomjit, B. (2019). Ethanol Dehydrogenation to Acetaldehyde over Activated Carbons-Derived from Coffee Residue. Bulletin of Chemical Reaction Engineering \& Catalysis, 14 (2): 268-282 (doi:10.9767/bcrec.14.2.3335.268-282)

Permalink/DOI: https://doi.org/10.9767/bcrec.14.2.3335.268-282

\section{Introduction}

It is known that residues of coffee grounds obtained from soluble coffee industries, are normally discarded as waste, resold or reused as

*Corresponding Author.

E-mail: bunjerd.j@chula.ac.th (B. Jongsomjit),

Telp: +66-22186874, Fax: +66-22186877 body scrub, facial mask, fertilizer or odoreliminator. However, these coffee residues can be currently used as raw material to produce high value-added activated carbons. Activated carbons have been widely used in many applications, especially as absorbents because of their excellent absorption capability for inorganic pollutants [1] and the removal of heavy metal from 
waste water [2]. Besides, they can be used as a catalyst or a catalyst support in the catalytic process [3,4], etc. Therefore, the search for alternative low-cost bio-based materials, as well as the appropriate processes for the preparation of activated carbons from these abundant resources, has become necessary [5,6]. The properties of activated carbons depend on the activation process and the nature of the source materials. Moreover, in both physical and chemical activation processes, knowledge of different variables is very important in developing the porosity of the carbons such as surface area, pore volumes, and porosity [1,7].

In general, the ways to prepare activated carbons can be divided into two types; physical activation and chemical activation. In the physical activation, a raw material is first carbonized, and then the carbonized material is activated by steam, carbon dioxide, air or their mixture. In the chemical activation, a raw material is impregnated with an activation agent, and then the impregnated material is heated under inert atmosphere. The carbonization step and activation step are carried out concurrently in the chemical activation process. Nevertheless, sometime the ways for preparing an activated carbon is modified (such as: chemical activation followed by physical activation) to improve characteristics of activated carbon (surface area and pore volume) [7,8]. This method occurs at lower temperature than that of physical methods. Therefore, it improves the pore development in the carbon structure. Types of chemical agent are selected to alter the characteristics of the desired activated carbon.

Previously, Almansa et al. [9] reported that $\mathrm{ZnCl}_{2}$ gave both wide micropores and low mesopores. Chemical activation with $\mathrm{ZnCl}_{2}$ has been studied by several researchers [8-10] using different preparation conditions. It is evident that the total coffee consumption in Thailand has been increasing every year during the past 15 years. In 2016, approximately 50,000-60,000 tons of coffee have been produced [11]. As a result, coffee residues are considered to be utilized efficiently. Previously, only a few researchers [12-15] used coffee ground residue as precursor for activated carbons. Mostly, they prepared the activated carbons using chemical activation with $\mathrm{ZnCl}_{2}, \mathrm{H}_{3} \mathrm{PO}_{4}$, and $\mathrm{KOH}$, and physical activation with $\mathrm{N}_{2}$ and $\mathrm{CO}_{2}$. In addition, Maraisa et al. [16] prepared activated carbons from coffee husk using chemical activation with $\mathrm{ZnCl}_{2}$ and physical activation with $\mathrm{N}_{2}$. The activated carbons obtained exhibited very high surface area larger than $890 \mathrm{~m}^{2} / \mathrm{g}$ indicat- ing that the coffee residue could be an economically promising material.

Ethanol can be used as fuel and fuel additive, but it is also very convincing as a platform chemical for the production of value-added chemicals, which are attractively growing concern in the last decade. It can be used as a renewable feedstock for both drop-in chemicals, such as: ethylene, diethyl ether, and 1,3-butadiene, as well as the production of oxygenated chemicals, such as: 1-butanol, ethyl acetate, acetic acid, acetaldehyde and ketone, because the process is relative simple, noncorrosive, green technology, less toxic, and always needs only one feedstock of ethanol. Dehydrogenation and dehydration of alcohol, which are catalyzed by carbon material have not been frequently studied. For ethanol, it can be converted into acetaldehyde via dehydrogenation reaction, which is one of important raw materials in production of chemicals (acetic acid, acetic anhydride, n-butanol, and 2ethylhexanol) [17]. The commercial production processes of acetaldehyde include dehydrogenation and oxidation of ethanol, the hydration of acetylene, the partial oxidation of hydrocarbons, and direct oxidation of ethylene. With the ever-growing of the world output of bioethanol, the production of acetaldehyde via dehydrogenation has been gradually considered as appropriate process [18]. The properties of catalysts, which are used to catalyze in ethanol reaction, have a great influence on the pathway mechanism leading to the desired products. For example, ethanol can be dehydrated into ethylene, diethyl ether using solid acid catalysts [19]. In addition, oxygenated chemicals, such as: acetaldehyde, can be produced from ethanol by dehydrogenation reaction with Lewis acid and basic catalysts [20].

In this present study, we firstly examine the characteristics of activated carbon produced from coffee ground residues from the soluble coffee cafe. This aims to determine the effects of different physical treatments and various activation times on the activated carbon properties including surface area and pore structures, crystal structure, acidity, basicity, and thermal properties, as well as morphological structures. Then, the activated carbons obtained were used as catalysts for dehydrogenation of ethanol to produce acetaldehyde.

\section{Materials and Methods}

\subsection{Materials}

The coffee residues used as the raw material to produce the activated carbon in this study 
were obtained from Starbucks Thailand. The chemicals used were as follows: zinc chloride (>98\% $\mathrm{ZnCl}_{2} ;$ Aldrich), hydrochloric acid (37\% $\mathrm{HCl}$; QReC), distilled water, 99\% nitrogen gas, and $99 \%$ carbon dioxide gas.

\subsection{Catalyst Preparation}

First, the coffee residue was washed with distilled water and dried at $110{ }^{\circ} \mathrm{C}$ for $24 \mathrm{~h}$. After cooling, the dried coffee residue was mixed with $\mathrm{ZnCl}_{2}$ with a mass ratio of coffee residue to $\mathrm{ZnCl}_{2}$ of $1: 3$ and dried in an oven at $110{ }^{\circ} \mathrm{C}$ for $24 \mathrm{~h}$. The mixture was then activated under only $\mathrm{CO}_{2}, \mathrm{~N}_{2}$ and $\mathrm{N}_{2}$ followed by $\mathrm{CO}_{2}$ atmosphere at $600{ }^{\circ} \mathrm{C}$ with a heating rate $10^{\circ} \mathrm{C} / \mathrm{min}$. Once the activation temperature was reached, it was kept for 1 and $4 \mathrm{~h}$ before cooling the furnace down to room temperature. Then, the samples were washed with $1 \mathrm{M} \mathrm{HCl}$, and followed several washed with distilled water. Finally, they were dried at $110{ }^{\circ} \mathrm{C}$ for $24 \mathrm{~h}$. The activated carbon nomenclature are given as shown. AC-A was activated under only $\mathrm{CO}_{2}$ flow for $4 \mathrm{~h}$. AC-B was activated under only $\mathrm{N}_{2}$ flow for $4 \mathrm{~h}$. AC-C was heated under $\mathrm{N}_{2}$ and hold under $\mathrm{CO}_{2}$ for $1 \mathrm{~h}$. AC-D was heated under $\mathrm{N}_{2}$ and hold under $\mathrm{CO}_{2}$ for $4 \mathrm{~h}$.

\subsection{Catalyst Characterization}

The surface area, pore volume, and pore diameter of the activated carbon were measured by $\mathrm{N}_{2}$ adsorption-desorption at liquid nitrogen temperature $\left(-196{ }^{\circ} \mathrm{C}\right)$ using a Micromeritics ASAP 2020 analyzer. The surface area and pore distribution were calculated according to the BET and BJH methods, respectively.

X-ray diffraction (XRD) was performed to determine crystalline structures of activated carbon and raw material using a Siemens D $5000 \mathrm{X}$-ray diffractometer having $\mathrm{Cu}-\mathrm{K} \alpha$ radiation with Ni filter in the $2 \theta$ range of 20-80 with a resolution of 0.04 .

Scanning electron microscopy (SEM; JEOL model JSM-5800LV) and energy dispersive Xray spectroscopy (EDX) were used to determine the morphology and elemental distribution of catalysts. Model of SEM: JEOL mode JSM5800LV was used and EDX was performed using Link Isis Series 300 program.

Temperature-programmed desorption of carbon dioxide $\left(\mathrm{CO}_{2}\right.$-TPD) was performed by using Micromeritics Chemisorp 2750 automated system to study the basic properties. In the study, $0.05 \mathrm{~g}$ of catalyst was packed in a U-tube quartz cell with $0.03 \mathrm{~g}$ of quartz wool and pretreated at $500{ }^{\circ} \mathrm{C}$ under helium flow rate 25 $\mathrm{cm}^{3} / \mathrm{min}$ for $1 \mathrm{~h}$. The catalyst sample was satu- rated with $\mathrm{CO}_{2}$ at ambient temperature. Then, the catalyst surface was physisorbed by the $\mathrm{He}$ flow rate $25 \mathrm{~cm}^{3} / \mathrm{min}$ for $30 \mathrm{~min}$. After that, the temperature-programmed desorption was carried out from $40{ }^{\circ} \mathrm{C}$ to $800{ }^{\circ} \mathrm{C}$ at heating rate of $10{ }^{\circ} \mathrm{C} / \mathrm{min}$. The amount of $\mathrm{CO}_{2}$ in effluent gas was analyzed via thermal conductivity detector (TCD) as a function of temperature. The total basicity was calculated from the relation of $\mathrm{TCD}$ and temperature from $40{ }^{\circ} \mathrm{C}$ to $550^{\circ} \mathrm{C}$. After $550{ }^{\circ} \mathrm{C}$, the TPD peak was only decomposition of catalyst as proven by the TGA result.

Temperature-programmed desorption of ammonia $\left(\mathrm{NH}_{3}\right.$-TPD) was performed using Micromeritics Chemisorp 2750 automated system to study the basic properties. In the study, 0.05 $\mathrm{g}$ of catalyst was packed in a U-tube quartz cell with $0.03 \mathrm{~g}$ of quartz wool and pretreated at $500{ }^{\circ} \mathrm{C}$ under helium flow rate $25 \mathrm{~cm}^{3} / \mathrm{min}$ for 1 h. The catalyst sample was saturated with $\mathrm{NH}_{3}$ at ambient temperature. Then, the catalyst surface was physisorbed by the He flow rate 25 $\mathrm{cm}^{3} / \mathrm{min}$ for $30 \mathrm{~min}$. After that, the temperature programmed desorption was carried out from $40^{\circ} \mathrm{C}$ to $800{ }^{\circ} \mathrm{C}$ at heating rate $10^{\circ} \mathrm{C} / \mathrm{min}$. The amount of $\mathrm{NH}_{3}$ in effluent gas was analyzed via thermal conductivity detector (TCD) as a function of temperature. The total acidity was calculated from the relation of TCD and temperature from $40{ }^{\circ} \mathrm{C}$ to $550{ }^{\circ} \mathrm{C}$. After 550 ${ }^{\circ} \mathrm{C}$, the TPD peak was only decomposition of catalyst as proven by the TGA result as also mentioned before.

The Fourier transform infrared (FTIR) spectrometry was applied in the characterization of the functional groups of the activated carbon prepared. To obtain the observable absorption spectra, it was performed using Nicolet 6700 FTIR spectrometer in the range of 400 to 4000 $\mathrm{cm}^{-1}$.

Thermogravimetric analysis (TGA) was performed using an SDT Analyzer Model Q600 from TA Instruments (USA). The TGA analyses of the activated carbon were carried out from room temperature to $900{ }^{\circ} \mathrm{C}$ at a heating rate of $10{ }^{\circ} \mathrm{C} / \mathrm{min}$ under nitrogen atmosphere at the flow rate of $100 \mathrm{~mL} / \mathrm{min}$.

\subsection{Catalytic Tests}

\subsubsection{Temperature-programmed reaction}

The similar ethanol reaction system as reported by Krutpijit and Jongsomjit [19] was used. The catalytic dehydrogenation of ethanol was performed in the fixed-bed continuous flow microreactor. First, $0.05 \mathrm{~g}$ of catalyst and 0.01 $\mathrm{g}$ of quartz wool bed were packed in the middle of glass tube reactor, which is located in the 
electric furnace. Before the reaction was carried out, catalyst was preheated at $200{ }^{\circ} \mathrm{C}$ for $30 \mathrm{~min}$ in nitrogen to remove the moisture. The liquid ethanol was vaporized at $120^{\circ} \mathrm{C}$ with nitrogen gas $(60 \mathrm{~mL} / \mathrm{min})$ by controlled injection with a single syringe pump at a constant flow rate of ethanol at $1.45 \mathrm{~mL} / \mathrm{h}$. The gas stream was introduced to the reactor with the weight hourly space velocity (WHSV) of $22.9 \quad$ geth. anol. cat $^{-1} \cdot \mathrm{h}^{-1}$ and the reaction was carried out at temperature range from $250{ }^{\circ} \mathrm{C}$ to $400{ }^{\circ} \mathrm{C}$ under atmospheric pressure. The gaseous products were analyzed by a Shimadzu (GC-14B) gas chromatograph with flame ionization detector (FID) using capillary column (DB-5) at $150{ }^{\circ} \mathrm{C}$. Upon the reaction test, at least three times for each sampling were recorded. The average values for ethanol conversion and product distribution as a function of temperature were reported.

\subsubsection{Stability Test}

The experimental apparatus and set-up were similar with the temperatureprogrammed reaction as mentioned above. The ethanol dehydrogenation temperature was kept at $400{ }^{\circ} \mathrm{C}$. After pretreatment catalyst for 30 min, the ethanol with WHSV of 22.9 gethanol. gcat $^{-1} \cdot \mathrm{h}^{-1}$ was fed into the reactor for $1 \mathrm{~h}$ before sampling the first product. Then, the effluent was collected every $1 \mathrm{~h}$ for $10 \mathrm{~h}$. Effluents were analyzed with the same method as mentioned before.

\section{Results and Discussion}

\subsection{Catalyst Characterization}

Table 1 shows the BET surface areas, pore

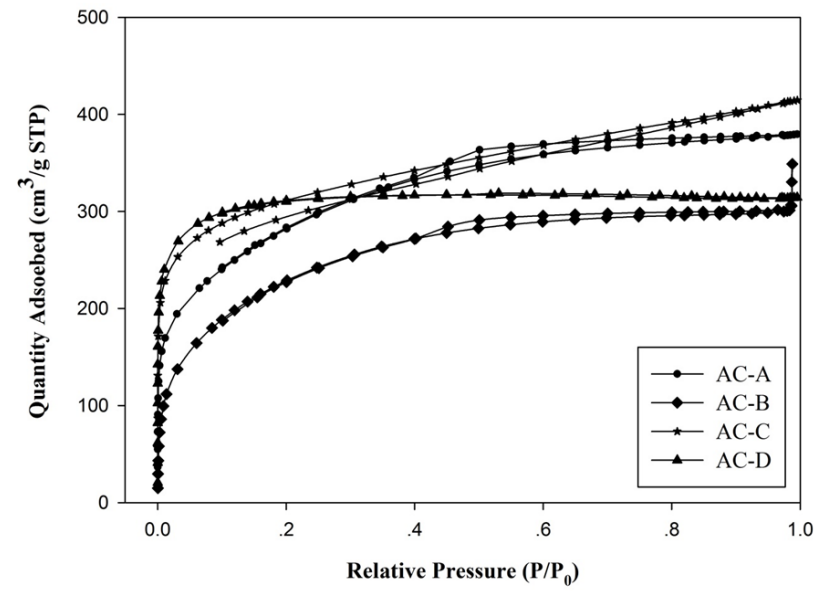

Figure 1. Adsorption-desorption isotherm at $196{ }^{\circ} \mathrm{C}$ of activated carbons at different activation conditions volume and pore size diameter of activated carbons prepared from $\mathrm{ZnCl}_{2}$ activation observed at different conditions of physical activation. The structural parameters obtained from the $\mathrm{N}_{2}$ adsorption-desorption are summarized in Table 1. Data are tabulated for BET area, total pore volume, micropore volume, average pore width, and the ratio of micropore volume to total pore volume (\% microporosity). It is quite evident that the AC-B (chemically activated only) sample exhibited the lowest surface area among other samples. Thus, a subsequent physical activation process was necessary to improve the textural characteristics [10]. Of the two chemically and physically activated samples, AC-C and AC-D exhibited high surface area, but AC-D showed the highest micropore volume of all samples. The micropore volume accounts for nearly $100 \%$ of the total pore volume of the sample [10].

The most common procedure for determining the structure of porosity and specific surface area of catalysts is the adsorptiondesorption of liquid nitrogen at $-196{ }^{\circ} \mathrm{C}$. Figure 1 shows the $\mathrm{N}_{2}$ adsorption-desorption isotherms of the activated carbons derived coffee ground residues prepared by different activation conditions. All catalysts exhibit a combination of Type-I and Type-IV isotherms [20], which usually represent the presence of both microporous initial relative pressure range, displaying that all catalysts present microporous structure. Furthermore, all catalysts also represent similar isotherm with hysteresis loop (between the adsorption and desorption isotherm) at high relative pressure $\left(P / P_{0}>0.4\right)$, indicating the formation of mesoporous structure [21-22]. Consequently, all catalysts are composed of both microporous and mesoporous structure. Of the two chemically and physically

Table 1. Pore characteristics for activated carbons

\begin{tabular}{lcccc}
\hline $\begin{array}{c}\text { Activated } \\
\text { carbons }\end{array}$ & AC-B & AC-A & AC-C & AC-D \\
\hline$S_{B E T}\left(\mathrm{~m}^{2} / \mathrm{g}\right)$ & 797 & 967 & 1,045 & 1,037 \\
$V_{t}\left(\mathrm{~cm}^{3 / g}\right)$ & 0.47 & 0.59 & 0.64 & 0.49 \\
$V_{m i c}\left(\mathrm{~cm}^{3} / \mathrm{g}\right)$ & 0.36 & 0.43 & 0.42 & 0.49 \\
$\% V_{m i c}$ & 76.7 & 72.7 & 65.3 & 100 \\
$D_{p}(\mathrm{~nm})$ & 2.4 & 2.4 & 2.4 & 1.9 \\
\hline
\end{tabular}

$S_{B E T}$ : BET surface area; $V_{t}$ : total pore volume; $V_{m i c}$ : micropore volume; $\% V_{\text {mic }},\left(V_{\text {mic }} / V_{t}\right) \times 100 ; D_{p}$, average pore diameter calculated as $4 \mathrm{~V} / \mathrm{A}$ by BET 
activated samples (AC-C sample) shows the highest nitrogen adsorption capacity, which relates to high pore volume in Table 1 . In addition, the activated carbon (AC-D) has a main Type-I isotherm associating with origination of complete micropore structure [23] in Table 1.

The $\mathrm{NH}_{3}$-TPD can be used to examine the total acidity of the catalysts as also shown in Table 2. The $\mathrm{NH}_{3}$-TPD profiles are also shown in Figure 2 indicating that all catalysts mainly contained strong acid. The total acidity of activated carbons, which is in the order from the greatest to the least as following: AC-D > AC-C $>\mathrm{AC}-\mathrm{A}>\mathrm{AC}-\mathrm{B}>\mathrm{AC}-\mathrm{COM}$. It notices that ACD sample exhibits the highest total acid density, which is $647 \mu \mathrm{mol} / \mathrm{g}$. The $\mathrm{CO}_{2}$-TPD was used to investigate the total basicity of the catalysts. The $\mathrm{CO}_{2}$-TPD profiles are also shown in Figure 3 indicating that all catalysts mainly contained strong base. The results as also seen in Table 2 show that AC-B catalyst has the greatest basicity followed by AC-D, which is shown high value of both acidity and basicity.

Table 2. Total acidity and total basicity of activated carbons

\begin{tabular}{ccc}
\hline $\begin{array}{c}\text { Activated } \\
\text { carbons }\end{array}$ & $\begin{array}{c}\text { Total acidity } \\
(\mu \mathrm{mol} / \mathrm{g})\end{array}$ & $\begin{array}{c}\text { Total basicity } \\
(\mu \mathrm{mol} / \mathrm{g})\end{array}$ \\
\hline AC-A & 450.27 & 15.01 \\
AC-B & 602.15 & 10.48 \\
AC-C & 617.04 & 11.34 \\
AC-D & 646.82 & 13.70 \\
AC-COM & 132.97 & 7.83 \\
\hline a $\mathrm{NH}_{3}-\mathrm{TPD}$ & & \\
${ }^{\mathrm{b}} \mathrm{CO}_{2}$-TPD & &
\end{tabular}

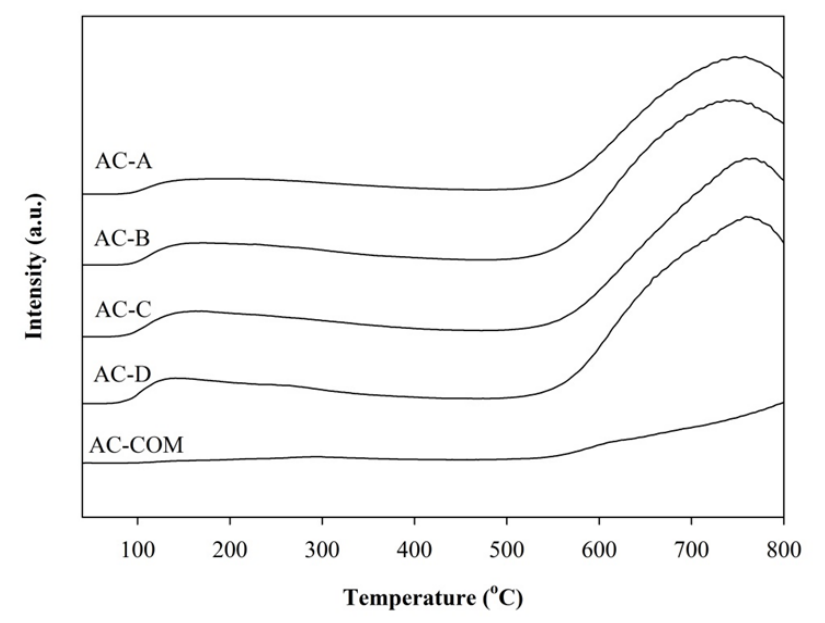

Figure 2. $\mathrm{NH}_{3}-\mathrm{TPD}$ profiles of activated carbons
The order of the total basicity is shown as followed: AC-C > AC-A > AC-COM. The results of catalytic performance of all activated carbon catalysts toward the dehydrogenation of ethanol under steady-state conditions are presented in Table 4 and depicted in Figure 9.

Figure 4 shows XRD patterns of activated carbon catalysts prepared by various activation methods. In all samples, there are broad diffraction peak around $2 \theta=22.5^{\circ}$, which can be denoted as amorphous carbon composed of aromatic carbon sheets [24]. In addition, broad diffraction peak around $2 \theta=45^{\circ}$ is defined as graphite structure. The morphologies of activated carbons are shown in Figure 5. Considering all activated carbons from chemical activation by $\mathrm{ZnCl}_{2}$, the activation process resulted in a substantial removal of inorganic material that can be seen in the micrographs [8] and all of activated carbons show the same morphology. In addition, it is clearly seen that the peaks

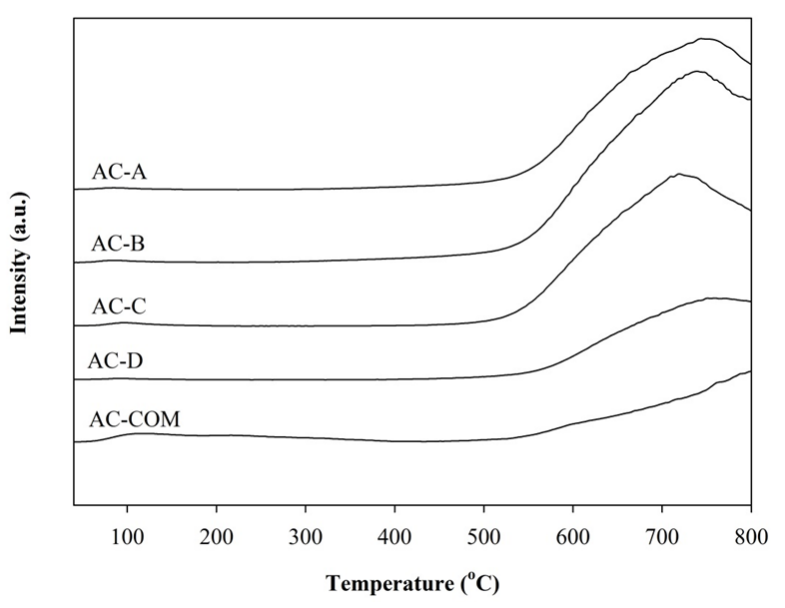

Figure 3. $\mathrm{CO}_{2}$-TPD profiles of activated carbons

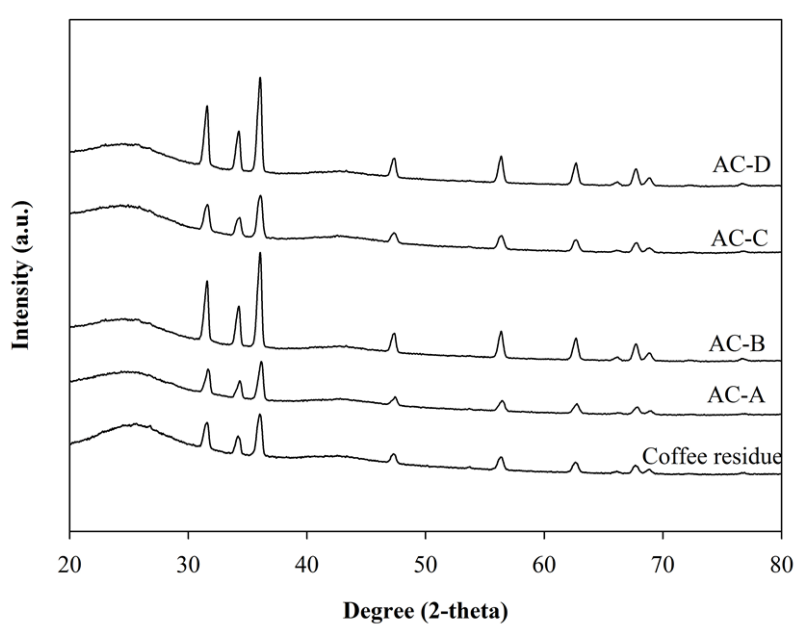

Figure 4. XRD patterns of activated carbons and coffee residue 


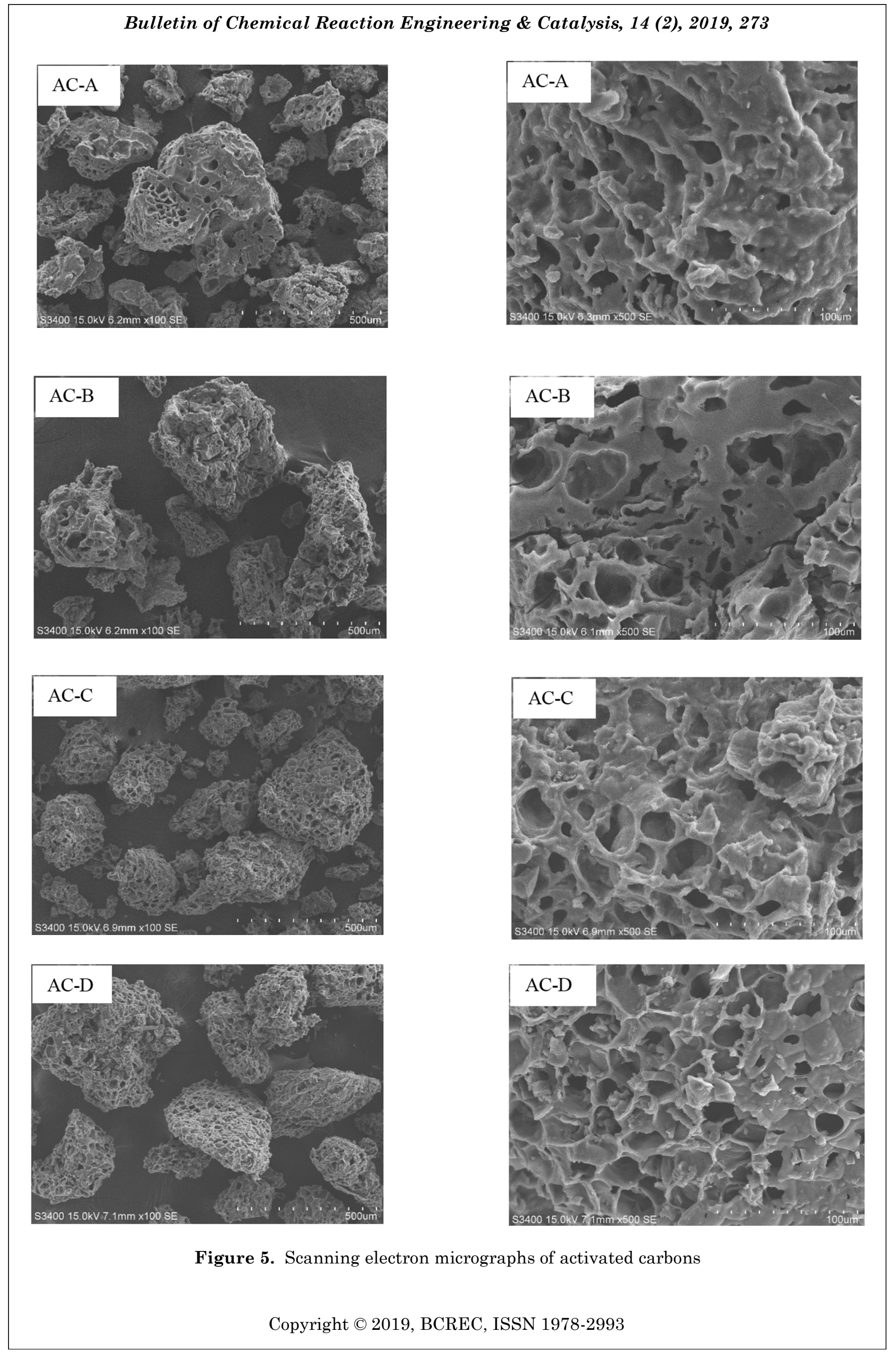


Table 3. Functional group of activated carbons [26-29]

\begin{tabular}{|c|c|c|c|}
\hline Catalysts & Assignment & Remark & Wave number $\left(\mathrm{cm}^{-1}\right)$ \\
\hline \multirow{10}{*}{ AC-A } & $\mathrm{O}-\mathrm{H}$ stretching & $\begin{array}{l}\text { Hydroxyl group as alcohol / phe- } \\
\text { nol }\end{array}$ & 3328 \\
\hline & $\mathrm{C} \equiv \mathrm{C}$ & Alkyne groups & 2361 \\
\hline & $\mathrm{C} \equiv \mathrm{C}$ & Alkyne groups & 2160 \\
\hline & $\begin{array}{l}\mathrm{C}=\mathrm{C} \text { asymmetric } \\
\text { stretch }\end{array}$ & Alkene groups & 2025 \\
\hline & $\begin{array}{l}\mathrm{C}=\mathrm{C} \text { asymmetric } \\
\text { stretch }\end{array}$ & Alkene groups & 1976 \\
\hline & $\mathrm{C}=\mathrm{O}$ stretching & Carboxylic acids & 1740 \\
\hline & $\mathrm{C}-\mathrm{O}$ & Esters, ether or phenol groups & 973 \\
\hline & $\mathrm{C}-\mathrm{H}$ & Benzene derivates & 744 \\
\hline & $\mathrm{C}-\mathrm{Cl}$ & Alkyl Halide & 709 \\
\hline & $\mathrm{O}-\mathrm{H}$ & Hydroxyl group & 657 \\
\hline \multirow{12}{*}{ AC-B } & $\mathrm{O}-\mathrm{H}$ stretching & Ethers & 3266 \\
\hline & $\mathrm{C}-\mathrm{H}$ stretching & With carbon surface & 2970 \\
\hline & $\mathrm{C} \equiv \mathrm{C}$ & Alkyne groups & 2361 \\
\hline & $\mathrm{C} \equiv \mathrm{C}$ & Alkyne groups & 2160 \\
\hline & $\begin{array}{l}\mathrm{C}=\mathrm{C} \text { asymmetric } \\
\text { stretch }\end{array}$ & Alkene groups & 2025 \\
\hline & $\begin{array}{l}\mathrm{C}=\mathrm{C} \text { asymmetric } \\
\text { stretch }\end{array}$ & Alkene groups & 1975 \\
\hline & $\mathrm{C}=\mathrm{O}$ stretching & Carboxylic acids & 1743 \\
\hline & $\mathrm{C}=\mathrm{C}$ & Aromatics group & 1511 \\
\hline & $\mathrm{C}-\mathrm{O}$ & Esters, ether or phenol groups & 1013 \\
\hline & $\mathrm{C}-\mathrm{H}$ & Benzene derivates & 743 \\
\hline & $\mathrm{C}-\mathrm{Cl}$ & Alkyl Halide & 709 \\
\hline & $\mathrm{O}-\mathrm{H}$ & Hydroxyl group & 656 \\
\hline \multirow{11}{*}{$\mathrm{AC}-\mathrm{C}$} & $\mathrm{O}-\mathrm{H}$ stretching & Hydroxyl group as alcohol & 3745 \\
\hline & $\mathrm{C}-\mathrm{H}$ stretching & With carbon surface & 2968 \\
\hline & $\mathrm{C} \equiv \mathrm{C}$ & Alkyne groups & 2161 \\
\hline & $\begin{array}{l}\mathrm{C}=\mathrm{C} \text { asymmetric } \\
\text { stretch }\end{array}$ & Alkene groups & 2025 \\
\hline & $\begin{array}{l}\mathrm{C}=\mathrm{C} \text { asymmetric } \\
\text { stretch }\end{array}$ & Alkene groups & 1975 \\
\hline & $\mathrm{C}=\mathrm{O}$ stretching & Carboxylic acids & 1741 \\
\hline & $\mathrm{C}=\mathrm{C}$ & Aromatics group & 1513 \\
\hline & $\mathrm{C}-\mathrm{H}$ & Alkanes, alkyl groups & 1456 \\
\hline & $\mathrm{C}-\mathrm{O}$ & Carboxylate group & 1365 \\
\hline & $\mathrm{C}-\mathrm{O}$ & Esters, ether or phenol groups & 1013 \\
\hline & $\mathrm{C}-\mathrm{Cl}$ & Alkyl Halide & 712 \\
\hline
\end{tabular}


Table 3. Functional group of activated carbons [26-29] (continued)

\begin{tabular}{|c|c|c|c|}
\hline Catalysts & Assignment & Remark & Wave number $\left(\mathrm{cm}^{-1}\right)$ \\
\hline \multirow{12}{*}{ AC-D } & $\mathrm{O}-\mathrm{H}$ stretching & Hydroxyl group as alcohol & 3746 \\
\hline & $\mathrm{C}-\mathrm{H}$ stretching & With carbon surface & 2970 \\
\hline & $\mathrm{C} \equiv \mathrm{C}$ & Alkyne groups & 2362 \\
\hline & $\mathrm{C} \equiv \mathrm{C}$ & Alkyne groups & 2160 \\
\hline & $\begin{array}{l}\mathrm{C}=\mathrm{C} \text { asymmetric } \\
\text { stretch }\end{array}$ & Alkene groups & 2024 \\
\hline & $\begin{array}{l}\mathrm{C}=\mathrm{C} \text { asymmetric } \\
\text { stretch }\end{array}$ & Alkene groups & 1976 \\
\hline & $\mathrm{C}=\mathrm{C}$ & Carbonyl group & 1741 \\
\hline & $\mathrm{C}-\mathrm{O}$ & Carboxylate group & 1365 \\
\hline & $\mathrm{C}-\mathrm{O}$ & Esters, ether or phenol groups & 1206 \\
\hline & $\mathrm{C}-\mathrm{O}$ & Esters, ether or phenol groups & 1006 \\
\hline & $\mathrm{C}-\mathrm{H}$ & Benzene derivates & 740 \\
\hline & $\mathrm{O}-\mathrm{H}$ & Hydroxyl group & 656 \\
\hline \multirow{8}{*}{$\mathrm{AC}-\mathrm{COM}$} & $\mathrm{O}-\mathrm{H}$ stretching & Ethers & 3564 \\
\hline & $\mathrm{C} \equiv \mathrm{C}$ & Alkyne groups & 2161 \\
\hline & $\begin{array}{l}\mathrm{C}=\mathrm{C} \text { asymmetric } \\
\text { stretch }\end{array}$ & Alkene groups & 2026 \\
\hline & $\mathrm{C}=\mathrm{O}$ stretching & Carboxylic acids & 1734 \\
\hline & $\mathrm{C}-\mathrm{O}$ & Carboxylate group & 1366 \\
\hline & $\mathrm{C}-\mathrm{O}$ & Esters, ether or phenol groups & 1214 \\
\hline & $\mathrm{C}-\mathrm{H}$ & Benzene derivates & 775 \\
\hline & $\mathrm{C}-\mathrm{Cl}$ & Alkyl Halide & 713 \\
\hline
\end{tabular}
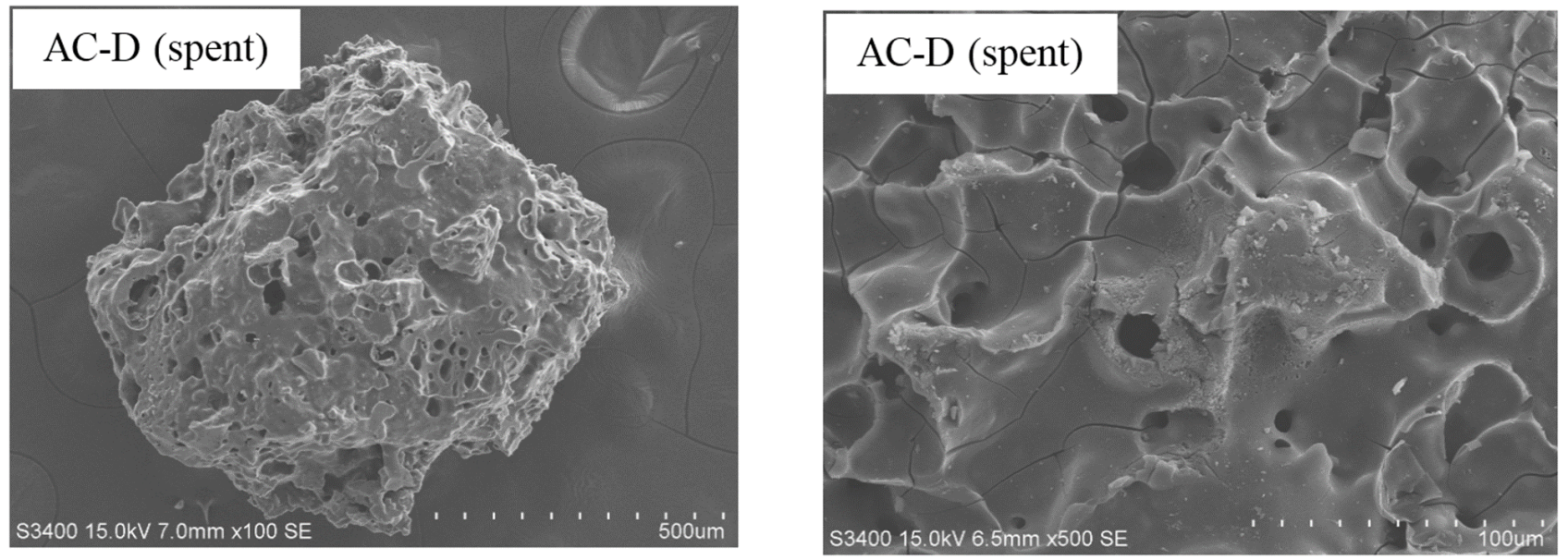

Figure 6. Scanning electron micrographs of spent AC-D catalyst after ethanol dehydrogenation 
located at $2 \theta=31-38^{\circ}, 47^{\circ}, 56^{\circ}, 62^{\circ}$, and $67-69^{\circ}$ were remained. This shows that when larger particles are sieved out, the remaining small particles are the mixture of amorphous and a small amount of graphitize carbon [25].

The FT-IR is the common technique to examine the chemical structure of activated carbon as oxygen functional groups. Figure 7
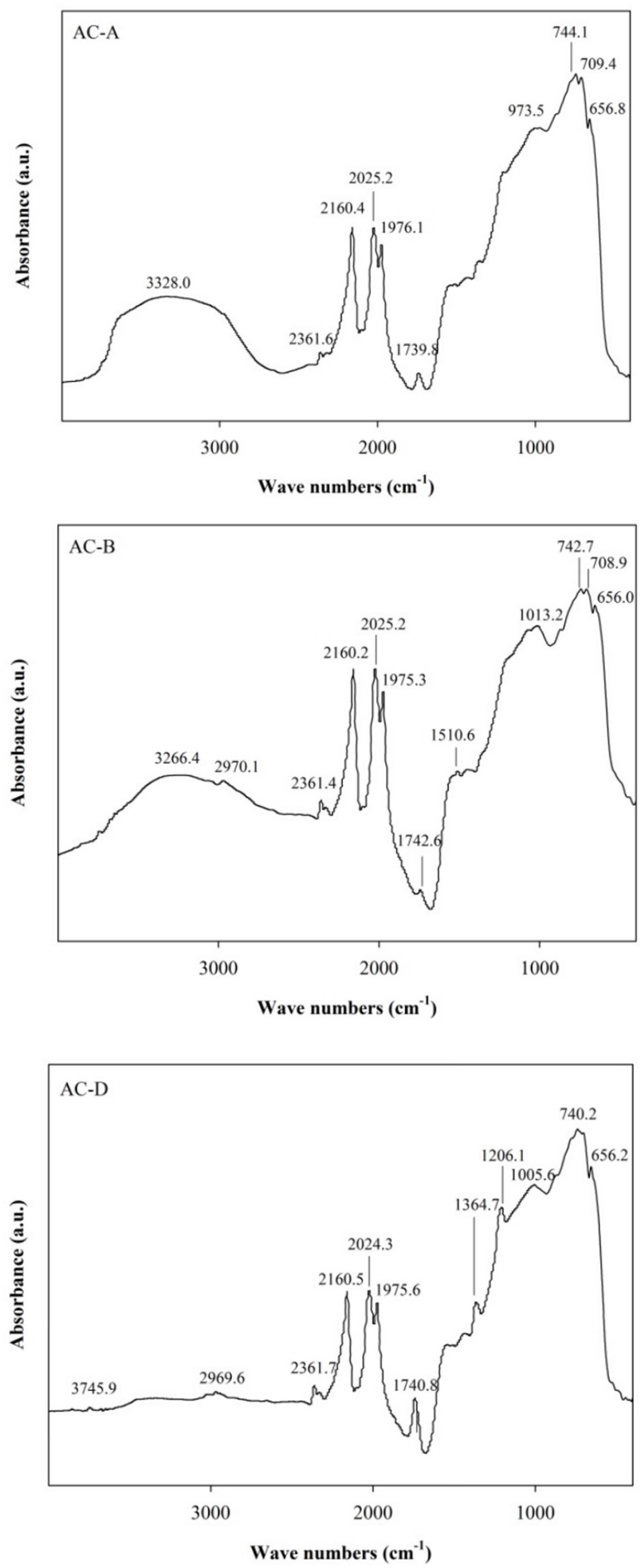

shows FT-IR spectra of activated carbon derived from coffee found residues with different methods of activations. Details of functional group assignment are illustrated in Table 3 . All catalysts show band in range of $600-3800$ $\mathrm{cm}^{-1}$. The broad band located around $3328 \mathrm{~cm}^{-1}$ could be attributed to the $\mathrm{O}-\mathrm{H}$ stretching vibration of hydroxyl group as alcohols and phenol or/and hydrogen bonded-OH group as water molecule. The band at $2970 \mathrm{~cm}^{-1}$ is related to $\mathrm{C}-\mathrm{H}$ interaction with carbon surface. The sharp bands located at $2361 \mathrm{~cm}^{-1}$ are attributed to the $\mathrm{C} \equiv \mathrm{C}$ stretching vibration of alkyne group. There is the shape band at $1742 \mathrm{~cm}^{-1}$, which can be denoted as stretching $\mathrm{C}=\mathrm{O}$ of carbonyl groups. Previously, Shafeeyan et al. [26] claimed that the IR band around 1720$1750 \mathrm{~cm}^{-1}$ is ascribed to the $\mathrm{C}=\mathrm{O}$ stretching of carboxylic acids. The region around 1364 and $1212 \mathrm{~cm}^{-1}$ may relate to $\mathrm{C}-\mathrm{O}$ stretching vibration from ethers [26]. In fact, carboxyl, anhydride and lactone are acidic, while phenol, carbonyl, quinine, and ether are neutral or weak
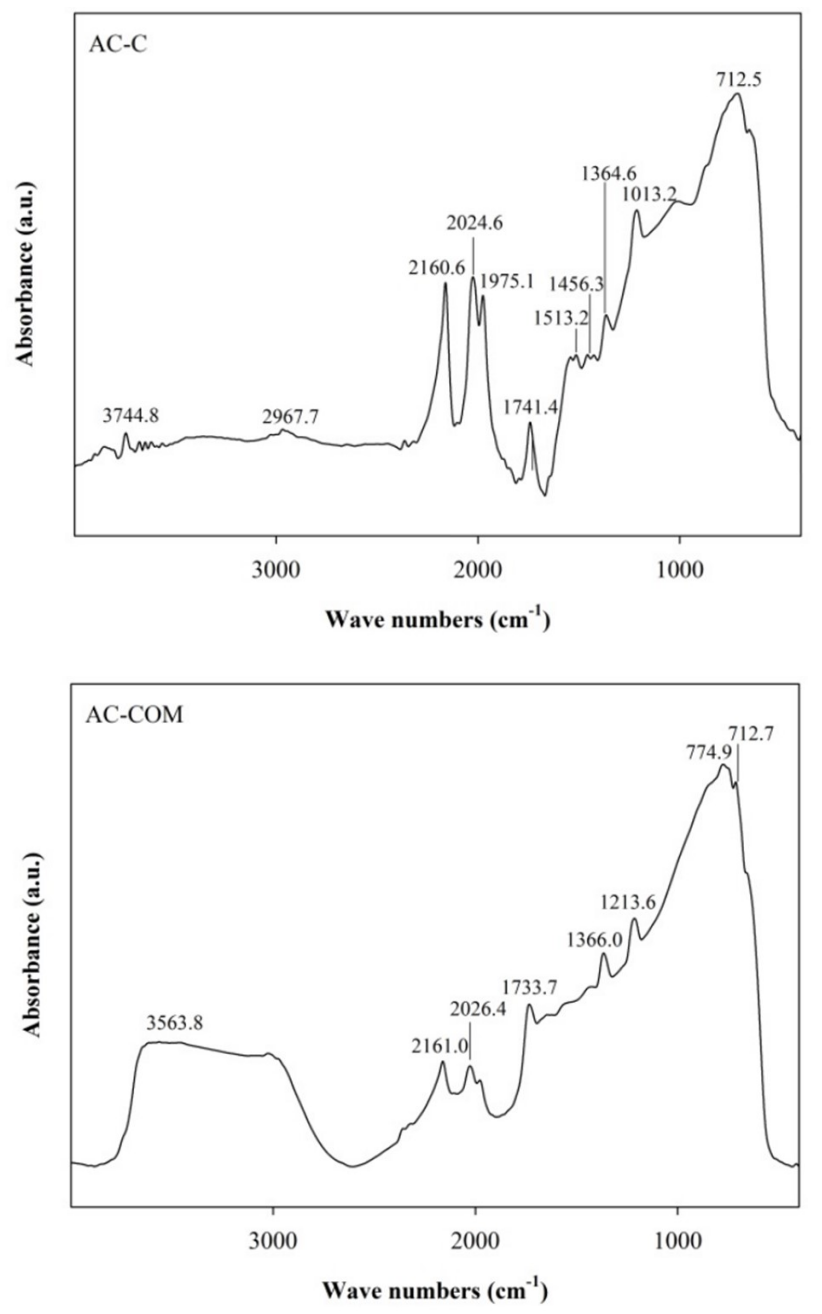

Figure 7. FTIR spectra of activated carbons 
acid. Consequently, the presence of oxygen surface functional group may be associated with the total acidity. It appears that the result from IR spectra is consistent with the total acid density obtained using $\mathrm{NH}_{3}$-TPD method [30].

The results of thermogravimetric analysis of activated carbons are presented in Figure 8. The mass loss during the thermogravimetric analysis can be divided into stages [8]. The initial mass loss for temperature up to $200{ }^{\circ} \mathrm{C}$ can be attributed to moisture elimination. The second stage is found at $200-300{ }^{\circ} \mathrm{C}$ range indicating the volatilization of organic materials. The third stage was found in the $300-600{ }^{\circ} \mathrm{C}$ range
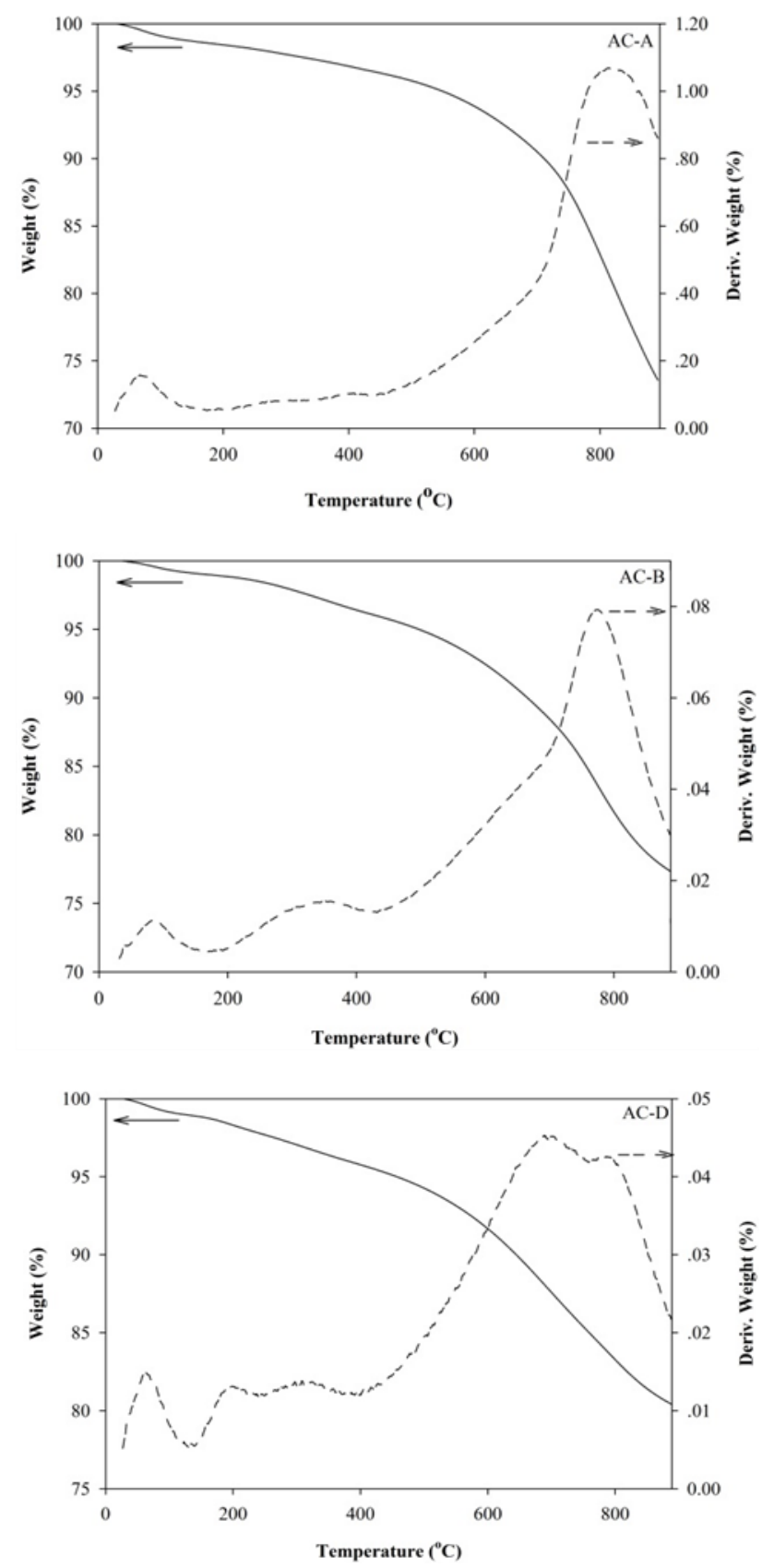

that may be attributed to further thermal decomposition of organic materials. Above 600 ${ }^{\circ} \mathrm{C}$, the mass loss is likely attributed to the reaction between the activating agent and carbonaceous residue. These results are also in agreement with other researchers [8].

\subsection{Dehydrogenation of Ethanol}

Considering the reaction study, Figure 9 represents the steady state conversion of ethanol for each temperature on the activated carbon catalysts derived from coffee ground residues with different activation methods. In addition, ethanol conversion and acetaldehyde yield for all catalysts are shown in Table 4. As expected, ethanol conversion increases with increasing the reaction temperature because of its endothermic reaction. According to the literature, ethanol decomposition leads to ethylene and diethyl ether by dehydration process and acetaldehyde by dehydrogenation process. The reaction of dehydrogenation takes place in a simultaneous presence of Lewis base and acid center, while that of dehydration involves only acid center [24]. In order to better understand the dehydrogenation process, the mechanism of ethanol to acetaldehyde by Lewis acid and
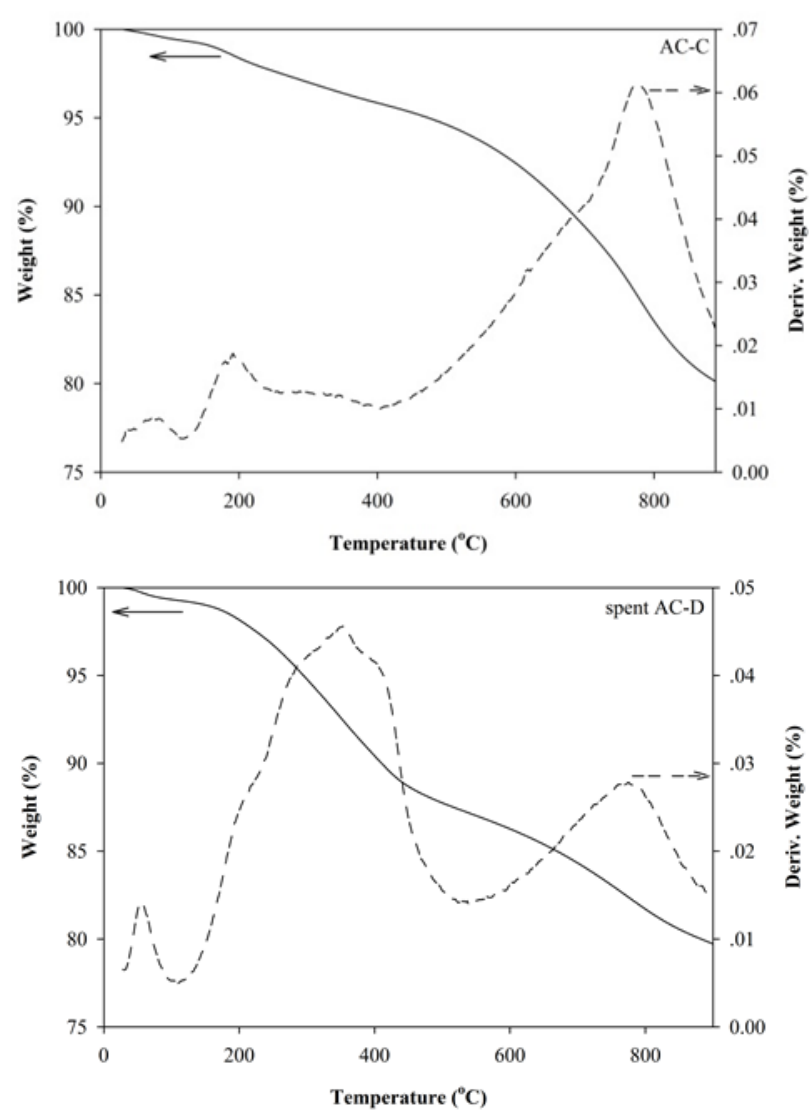

Figure 8. Thermal analysis of fresh activated carbons and spent AC-D catalyst 

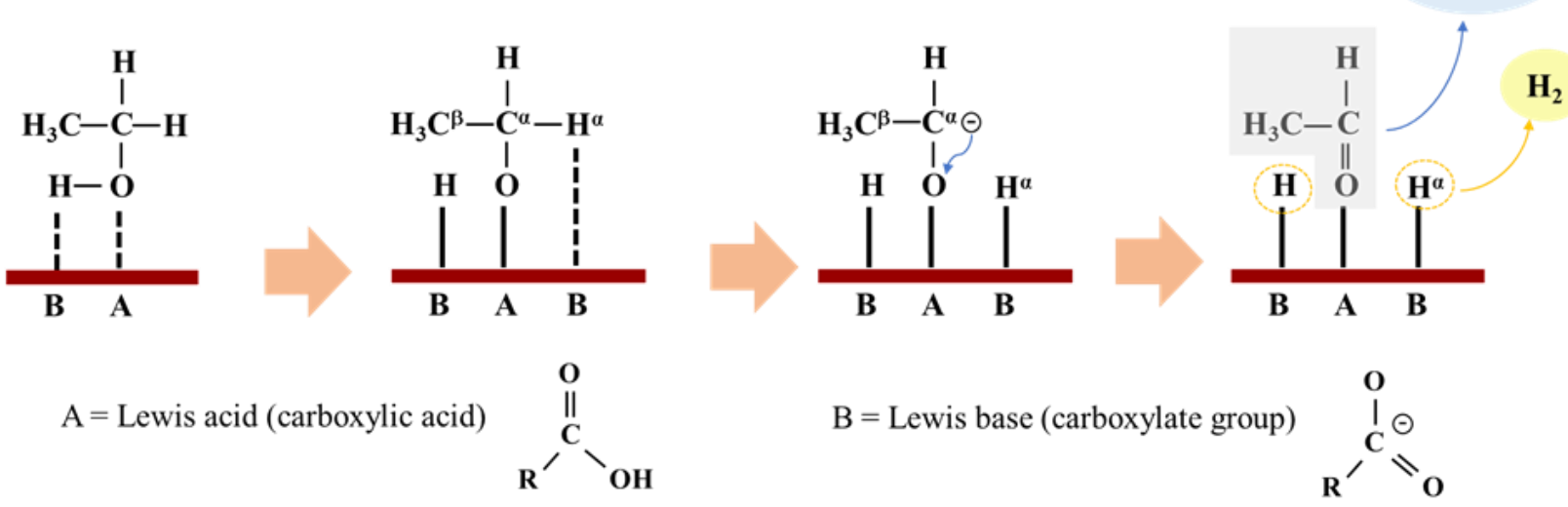

Scheme 1. Mechanism of ethanol to acetaldehyde by Lewis acid and Lewis base sites on activated carbon catalyst

Table 4. Ethanol conversion and acetaldehyde yield for all catalysts

\begin{tabular}{cccc}
\hline Samples & Temperatures $\left({ }^{\circ} \mathrm{C}\right)$ & $\mathrm{C}_{2} \mathrm{H}_{5} \mathrm{OH}$ conversion (\%) & $\mathrm{CH}_{3} \mathrm{CHO}$ yield (\%) \\
\hline \multirow{3}{*}{ AC-A } & 250 & 0.2 & 0.2 \\
& 300 & 0.8 & 0.8 \\
& 350 & 8.1 & 7.9 \\
& 400 & 32.3 & 31.7 \\
\hline \multirow{3}{*}{ AC-B } & 250 & 0.8 & 0.8 \\
& 300 & 4.5 & 4.4 \\
& 350 & 15.5 & 14.9 \\
AC-C & 400 & 27.8 & 26.8 \\
& 250 & 0.5 & 0.5 \\
& 300 & 3.8 & 3.0 \\
& 350 & 10.4 & 10.1 \\
& 400 & 26.4 & 25.7 \\
\hline \multirow{3}{*}{ AC-D } & 250 & 0.4 & 0.4 \\
& 300 & 2.8 & 2.7 \\
& 350 & 16.0 & 15.8 \\
& 400 & 47.9 & 46.8 \\
\hline \multirow{2}{*}{ AC-COM } & 250 & 1.3 & 1.2 \\
& 300 & 3.2 & 2.9 \\
& 350 & 4.5 & 4.3 \\
& 400 & 4.6 & 4.4 \\
\hline
\end{tabular}


Lewis base sites on activated carbon catalyst is illustrated in Scheme 1. Results of the catalytic reaction test in this study ensured that all activated carbons acted as catalysts of ethanol dehydrogenation, but in different activity. For all temperature $\left(250-400{ }^{\circ} \mathrm{C}\right)$, it is obviously seen that the AC-D catalyst shows the highest activity among other catalysts. Especially at temperature of $400{ }^{\circ} \mathrm{C}$, the AC-D catalyst shows ethanol conversion about $48 \%$, while other catalysts (AC-A, AC-B, and AC-C) display lower ethanol conversion about $26-32 \%$, whereas ACCOM catalyst shows the lowest ethanol conversion only $4 \%$.

According to total acidity and total basicity results, it reveals that the AC-D catalyst has the highest total acidity $(647 \mu \mathrm{mol} / \mathrm{g})$ and high basicity $(14 \mu \mathrm{mol} / \mathrm{g})$. Therefore, this confirms that dehydrogenation of ethanol is dependent on both of acidity and basicity. The result agrees with the previous wok of CarrascoMarin F. et al. [31], who reported that ethanol conversion increased with rise in the total surface acidity and basicity of unoxidised carbon and carbon prepared by oxidizing treatment with $\left(\mathrm{NH}_{4}\right)_{2} \mathrm{~S}_{2} \mathrm{O}_{8}$. It should be noted that all synthesized activated carbon catalysts exhibit the selectivity of acetaldehyde more than $96 \%$ without significant side reactions. It is also evident from Jasinska et al. [24], who claimed that chlorinated carbon catalysts showed greater domination of the process of dehydrogenation over dehydration than the oxidised carbon samples. In addition, Perez-Cadenas et al. [32] claimed that chlorination leads to increased acidity of Lewis acid centres on the activated carbon, but on the other hand, it reduces acidity of the Bronsted centres. The comparison of catalytic performance of catalysts in this work and other catalysts is summarized in Table 5, which shows that this catalyst is quite promising among other previous catalysts.

Finally, the stability test of the best catalyst (AC-D) under time on steam of $10 \mathrm{~h}$ was also performed at the reaction temperature of 400 ${ }^{\circ} \mathrm{C}$. The stability result is shown in Figure 10 . The ethanol conversion is fairly constant within $8 \mathrm{~h}$ of reaction. After $8 \mathrm{~h}$, the ethanol conversion gradually decreased because of perhaps coke formation or pore blockage as shown in Figure 6 of the spent catalyst. The morphology of spent AC-D catalyst after reaction is shown in Figure 6. Some pores of this catalyst were lacerated because of the thermal destruction by long time reaction. In addition, thermal analy-

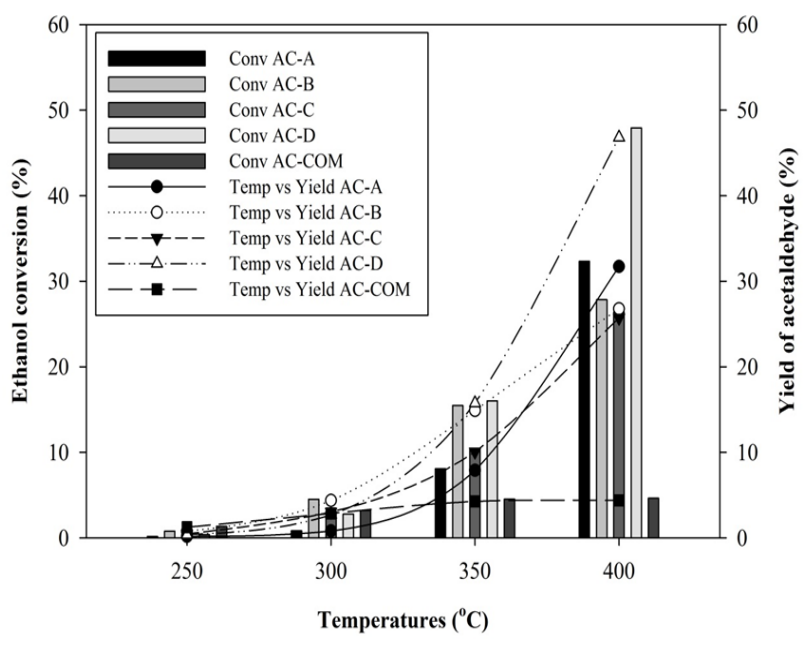

Figure 9. Ethanol conversion and acetaldehyde yield of activated carbon catalysts for ethanol dehydrogenation

Table 5. Comparison of carbon catalysts for ethanol dehydrogenation and their catalytic ability

\begin{tabular}{|c|c|c|c|c|c|c|}
\hline Catalysts & Source & $\begin{array}{l}\text { Surface area } \\
\qquad\left(\mathrm{m}^{2} / \mathrm{g}\right)\end{array}$ & $\begin{array}{l}\text { Reaction tem- } \\
\text { perature }\left({ }^{\circ} \mathrm{C}\right)\end{array}$ & $\begin{array}{c}\text { Ethanol } \\
\text { conversion } \\
(\%)\end{array}$ & $\begin{array}{l}\text { Acetaldehyde } \\
\text { yield (\%) }\end{array}$ & Refs \\
\hline AC-D & Coffee residue & 1,037 & 400 & 47.9 & 46.8 & $\begin{array}{l}\text { This } \\
\text { work }\end{array}$ \\
\hline $\mathrm{K} / \mathrm{Cl}_{2} / 4 \mathrm{~h} / 723 \mathrm{~K}$ & $\begin{array}{l}\text { Polish brown } \\
\text { coal }\end{array}$ & 2,374 & 477 & - & 75 & [20] \\
\hline AZ46-24 & Olive stones & 810 & 180 & 16.0 & 3.2 & [31] \\
\hline $\mathrm{MoO}_{3} / \mathrm{CMS}$ & $\begin{array}{l}\text { Carbon molecu- } \\
\text { lar sieve }\end{array}$ & - & 230 & 100 & 85 & [33] \\
\hline $\mathrm{C}-\mathrm{Ni}$ & $\begin{array}{l}\text { Polymeric car- } \\
\text { bon }\end{array}$ & - & 260 & - & 1 & [34] \\
\hline CNT-AO & $\begin{array}{l}\text { Carbon nano- } \\
\text { materials }\end{array}$ & 193 & 300 & 58.8 & 57.0 & [35] \\
\hline $50 \mathrm{Al} / \mathrm{BC}-\mathrm{TD}$ & $\begin{array}{l}\text { Bacterial cellu- } \\
\text { lose }\end{array}$ & 10.50 & 400 & 66.4 & 8.4 & [36] \\
\hline
\end{tabular}




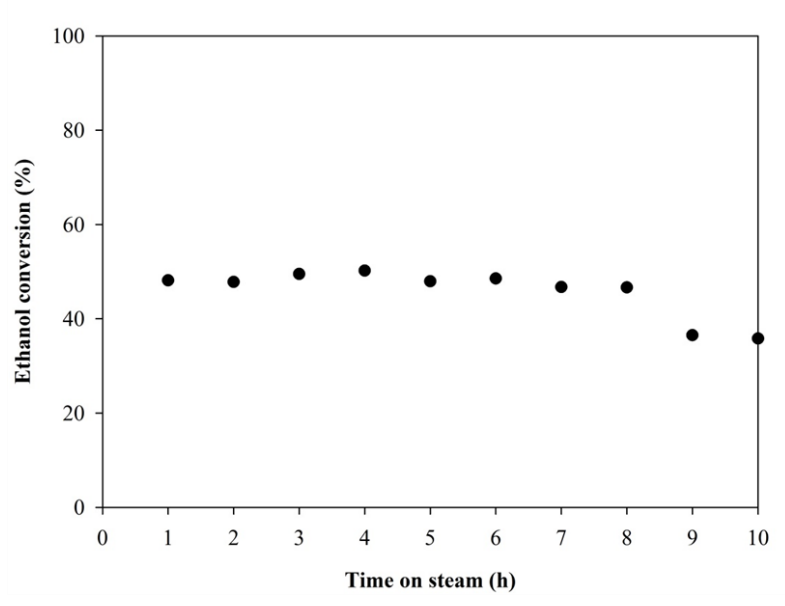

Figure 10. Stability test for AC-D catalyst at reaction temperature of $400{ }^{\circ} \mathrm{C}$

sis of the spent catalyst was performed as seen in Figure 8. The weight loss in other temperature ranges possibly came from desorption of other carbon compounds such as coke deposition and the adsorbed products, which was corresponding to the result of stability test as mentioned above. Moreover, the remained $\mathrm{Cl}$ on surface of spent catalyst (0.065 wt\%) apparently decreased from fresh catalyst (3.66 wt\%) due to the decomposition of $\mathrm{HCl}$ from the reaction between $\mathrm{ZnCl}_{2}$ with $\mathrm{H}_{2} \mathrm{O}$ [37] relating to TGA result in the decomposition temperature between 200 to $400{ }^{\circ} \mathrm{C}$.

\section{Conclusions}

The study revealed that the synthesized activated carbon from coffee ground residues with chemical activated by $\mathrm{ZnCl}_{2}$ followed by physical activated under carbon dioxide flow at 600 ${ }^{\circ} \mathrm{C}$ for 4 hours (AC-D), exhibited the highest activity with $48 \%$ conversion of ethanol and $47 \%$ yield of acetaldehyde at $400{ }^{\circ} \mathrm{C}$. The activation with $\mathrm{ZnCl}_{2}$ followed by $\mathrm{CO}_{2}$ at $600{ }^{\circ} \mathrm{C}$ for $4 \mathrm{~h}$ apparently resulted in increased acid and basic sites. The increase in the amount of Lewis acid and basic sites leads to enhance catalytic activity of ethanol dehydrogenation. All activated carbon catalysts in this study show very high selectivity to acetaldehyde (more than 90\%), which is quite promising compared to other activated carbon catalysts, which have significant side reactions. In addition, the synthesized activated carbon from coffee ground residues has an acceptable stability showing quite constant ethanol conversion under specified condition.

\section{Acknowledgments}

The authors thank the Grant for International Research Integration: Chula Research Scholar, Ratchadaphiseksomphot Endowment Fund and Grant for Research: Government Budget, Chulalongkorn University (2018) for financial support of this project.

\section{References}

[1] Zhou, M., Wang, W., Chi, M. (2009). Enhancement on the simultaneous removal of nitrate and organic pollutants from groundwater by a three-dimensional bioelectrochemical reactor. Bioresour. Technol., 100: 4662-4668.

[2] Yang, C., Liu, Y., Ma, C., Norton, M., Qiao, J. (2015). Preparing Desirable Activated Carbons from Agricultural Residues for Potential Uses in Water Treatment. Waste Biomass Valor., 6: 1029-1036.

[3] Bedia, J., Rosas, J.M., Rodriguez-Mirasol, J., Cordero, T. (2010). Pd supported on mesoporous activated carbons with high oxidation resistance as catalysts for toluene oxidation. Appl. Catal. B., 94: 8-18.

[4] Gu, J.Y., Li, K.X., Wang, J., He, H.W. (2010). Control growth of carbon nanofibers on $\mathrm{Ni}=$ activated carbon in a fluidized bed reactor. Microporous Mesoporous Mater., 131: 393-400.

[5] Guo, J., Lua, A.C. (2002). Microporous activated carbons prepared from palm shell by thermal activation and their application to sulfur dioxide adsorption. J. Colloid. Interface Sci., 251: 242-247.

[6] Maiti, S., Purakayastha, S., Ghosh, B. (2007). Production of low-cost carbon adsorbents from agricultural wastes and their impact on dye adsorption. Chem. Eng. Commun., 195: 386-403.

[7] Sekirifa, M.L., Hadj-Mahammed, M., Pallier, S., Baameur, L., Richard, D., Al-Dujaili, A.H. (2013). Preparation and characterization of an activated carbon from a date stones variety by physical activation with carbon dioxide. Journal of Analytical and Applied Pyrolysis, 99: 155-160.

[8] Niticharoenwong, B., Shotipruk, A., Mekasuwandumrong, O., Panpranot, J., Jongsomjit, B. (2013). Charasteristics of activated carbons derived from deoiled rice from rice bran residues. Chemical Engineering Communications, 200(10): 13091321.

[9] Almansa, C., Molina-Sabio, M., RodriguezReinoso, F. (2004). Adsorption of methane 
into $\mathrm{ZnCl}_{2}$-activated carbon derived discs. Microporous and Mesoporous Materials, 76: 185-191.

[10] Azevedo, D.C.S., Araujo, J.C.S., Bastos-Neto, M., Torres, A.E.B., Jaguaribe, E.F., Cavalcante, C.L. (2007). Microporous activated carbon prepared from coconut shells using chemical activation with zinc chloride. Microporous Mesoporous Mater., 100: 361364 .

[11] Department of Business Development. (12 November 2017). Citing Internet sources URL http://www.dbd.go.th/download/document_file /Statisic/2559/T26/T26_201612.pdf.

[12] Boudrahem, F., Aissani-Benissad F., AitAmar, H. (2009). Batch sorption dynamics and equilibrium for the removal of lead ions from aqueous phase using activated carbon developed from coffee residue activated with zinc chloride. Journal of Environmental Management, 90: 3031-3039.

[13] Boudrahem, F., Soualah, A., AissaniBenissad, F. (2011). Pb(II) and Cd(II) Removal from Aqueous Solutions Using Activated Carbon Developed from Coffee Residue Activated with Phosphoric Acid and Zinc Chloride. Journal of Chemical\& Engineering Data, 56: 1946-1955.

[14] Ngaosuwan, K., Goodwin Jr, J.G., Prasertdham, P. (2016). A green sulfonated carbon-based catalyst derived from coffee residue for esterification. Renewable Energy, 86: $262-269$.

[15] Laksaci, H., Khelifi, A., Trari, M., Addoun, A. (2017). Synthesis and characterization of microporous activated carbon from coffee grounds using potassium hydroxides. Journal of Cleaner Production, 147: 254-262.

[16] Goncalves, M., Guerreiro, M.C., Oliveira, L.C.A., Castro, C.S. (2013). A friendly environmental material: Iron oxide dispersed over activated carbon from coffee husk for organic pollutants removal. Journal of Environmental Management, 127: 206-211.

[17] Neramittagapong, A., Attaphaiboon, W., Neramittagapong, S. (2008). Acetaldehyde Production from Ethanol over Ni-Based Catalysts. Chiang Mai J. Sci., 35(1): 171 177.

[18] Freitasa, I.C., Damyanovab, S., Oliveirac, D.C., Marquesd, C.M.P., Buenoa, J.M.C. (2014). Effect of $\mathrm{Cu}$ content on the surface and catalytic properties of $\mathrm{Cu} / \mathrm{ZrO}_{2}$ catalyst for ethanol dehydrogenation. Journal of Molecular Catalysis A: Chemical, 381: 2637.

[19] Krutpijit, C., Jongsomjit, B. (2016). Catalytic Ethanol Dehydration over Different Acid- activated Montmorillonite Clays. Journal of Oleo Science, 65(4): 347-355.

[20] Gregg, S.J., Sing, K.S.W. (1982). Adsorption. London: Surface Area and Porosity, 2nd ed, Academic Press.

[21] Liou, T.H. (2004). Evolution of chemistry and morphology during the carbonization and combustion of rice husk. Carbon, 42: 785794.

[22] Kitano, M., Arai, K., Kodama, A., Kousaka, T., Nakajima, K., Hayashi, S., Hara, M. (2009). Preparation of a Sulfonated Porous Carbon Catalyst with High Specific Surface Area. Catalysis Letters, 131(1-2): 242-249.

[23] Goncalves, M., Guerreiro, M.C., Oliveira, L.C.A, Solar, C., Nazarro, M., Sapag, K. (2013). Micro Mesoporous Activated Carbon from Coffee Husk as Biomass Waste for Environmental Applications. Waste Biomass Valor., 4: 395-400.

[24] Jasinska, J., Krzyzynska, B., Kozlowski, M. (2011). Influence of activated carbon modifications on their catalytic activity in methanol and ethanol conversion reactions. Central European Journal of Chemistry, 9(5): 925-931.

[25] Yusof, J.M., Salleh, M.A.M., Rashid, S.A., Ismail, I., Adam, S.N. (2014). Characterisation of carbon particles (CPs) derived from dry milked kenaf biochar. Journal of Engineering Science and Technology Special Issue on Applied Engineering and Sciences, 10: 125 - 131.

[26] Shafeeyan, M.S., Daud, W.M.A.W., Houshmand, A., Shamiri, A. (2010). A review on surface modification of activated carbon for carbon dioxide adsorption. Journal of Analytical and Applied Pyrolysis, 89: 143151.

[27] Lua, A.C., Yang, T. (2004). Effect of activation temperature on the textural and chemical properties of potassium hydroxide activated carbon prepared from pistachio-nut shell. J. Colloid Interface Sci., 274(2): 594601.

[28] Vikulov, K., Coluccia, S., Martra, G. (1993). Fourier-transform Infrared Spectroscopic Studies of the Adsorption of Ketene on Silica. J. Chem. Soc. Faraday Trans., 89(7): 11211125.

[29] American University of Beirut. (12 May 2018). Citing Internet sources URL https://staff.aub.edu.lb/ tg02/IR.pdf.

[30] Tsai, W.T., Chang, C.Y., Lin, M.C., Chien, S.F., Sun, H.F., Hsieh, M.F. (2001). Adsorption of acid dye onto activated carbons prepared from agricultural waste bagasse by $\mathrm{ZnCl}_{2}$ activation. Chemosphere, 45(1): 51-58. 
[31] Carrasco-Marin, F., Mueden, A., MorenoCastilla, C. (1998). Surface-Treated Activated Carbons as Catalysts for the Dehydration and Dehydrogenation Reactions of Ethanol. $J$. Phys. Chem. B., 102: 9229-9244.

[32] Perez-Cadenas, A.F., Maldonado-Hodar, F.J., Moreno-Castilla, C. (2003). On the nature of suface acid sites of chlorinated activated carbons. Carbon, 41: 473-478.

[33] Grunewald, G.C., Drago, R.S. (1991). Carbon Molecular Sieves as Catalysts and Catalyst Supports. J. Am. Chem. Soc., 113: 1636-1639.

[34] Szymaiski, G.S., Rychlicki, G., Terzyk, A.P. (1994). Catalytic conversion of ethanol on carbon catalysts. Carbon, 32(2): 265-271.
[35] Tveritinova, E.A., Zhitnev, Y.N., Chernyak, S.A., Arkhipova, E.A., Savilov, S.V., Lunin, V.V. (2017). Catalytic Conversion of Aliphatic Alcohols on Carbon Nanomaterials: The Roles of Structure and Surface Functional Groups. Russian Journal of Physical Chemistry A, 91: 429-435.

[36] Abdulwahab, M.I., Khamkeaw, A., Jongsomjit, B., Phisalaphong, M. (2017). Bacterial Cellulose Supported Alumina Catalyst for Ethanol Dehydration. Catal. Lett., 147: 2462-2472.

[37] Jones, F., Tran, H., Lindberg, D., Zhao, L., Hupa, M. (2013). Thermal Stability of Zinc Compounds. Energy and Fuels, 27: 56635669 . 